\title{
FEEDBACK-GUIDED ANALYSIS AS AN APPROACH TO MANAGING SUSTAINABILITY IN ASEAN COUNTRIES
}

\author{
MARIA ASSUNTA C. CUYEGKENG (corresponding author) \\ Department of Leadership \& Strategy \\ John Gokongwei School of Management \\ Ateneo de Manila University, Quezon City, Philippines \\ acuyegkeng@ateneo.edu
}

\section{CHARLOTTE KENDRA GOTANGCO GONZALES}

Department of Environmental Science

School of Science and Engineering

Ateneo de Manila University, Quezon City, Philippines

kgotangco@ateneo.edu

\begin{abstract}
Innovation has been at the center of most science policies of the ASEAN countries, driven as they are by a greater concern for the competitive advantages that can come from science and technology. Related to these policies, although often treated separately, are policies on the environment and environmental education. What is missing, however, is a more comprehensive view of how both science and environmental policies influence and are influenced by the culture and well-being of the people in a particular country. This study attempts to fill in the blanks through feedback-guided analysis, particularly by using a cultural adaptation template introduced by Newell and Proust (2017b). It studies four subsystems and seven links, and shows how ASEAN science and environment policies, cultural paradigms, the state of ecosystems, and human health and well-being affect each other directly or indirectly. The cultural adaptation template indicates the need for a systems-thinking approach in managing innovation or the implementation of policy to ensure that well-meaning initiatives may not lead to unintended consequences.
\end{abstract}

\section{KEYWORDS}

cultural adaptation template; feedback-guided analysis;

ASEAN science and environmental policies; ASEAN cultural paradigms; systems-thinking 


\section{INTRODUCTION}

The science policies of ASEAN countries, driven by a greater concern for the competitive advantages that can come from science and technology, are often associated with innovation (Ambashi, 2018; Damuri, Aswicahyono, \& Christian, 2018; Narayanan \& Yew-Wah, 2018; Quimba, Albert, \& Llanto, 2018; Lim, 2018; Rattanakhamfu \& Tangkitvanich, 2018; Vo, Nguyen, \& Dinh, 2018; KOICA \& KISTEP, 2013). Policies on the environment and environmental education, despite being related to policies on science, are often treated separately (Anbumozhi \& Kojima, 2019; Tay \& Tijaja, 2017; Mokthsim \& Salleh, 2014; Chandran, Gunawardena, \& Castro, 2017; Socialist Republic of Viet Nam, 2012, among others). Yet what Lim (2018) says about successful innovation can also be said about what is needed to make both these science and environment policies effective, i.e., it "requires a complex ecosystem of effective institutions, laws, rules, and regulations that are managed by able and effective public officials and strongly supported by the private sector" (p. 213).

Faced with numerous concerns that promote the priorities of segmented offices, the challenge for policymakers and those implementing such policies in ASEAN countries is to understand the big picture, achieve the health and well-being of the population, and improve the state of the ecosystem. This study will attempt to describe this picture and show how a systems-thinking approach in managing innovation or implementing policy may help ensure that unintended negative consequences are avoided. It uses examples from the ten countries that make up ASEAN (Brunei, Cambodia, Indonesia, Laos, Malaysia, Myanmar, the Philippines, Singapore, Thailand, and Vietnam) given a number of commonalities between their science and environmental policies. Most of the ASEAN countries, moreover, have similar natural resources, weather patterns, and geologic profiles which may lead to similar sustainability concerns.

There has also been some growth of interest in ecological education, an extended form of environmental education which, in practice, has focused on the knowledge of and methodologies for studying environmental problems to develop a citizenry that can make wise choices regarding the impact of anthropological activities. Ecological education involves 
connotes an emphasis on the inescapable embeddedness of human beings in natural settings and [on] the responsibilities that arise from this relationship. (Smith \& Williams, 1999)

Ecological culture, along with the beliefs and practices embedded in our lifestyles, may thus influence the future of global sustainability. It refers to the way human beings conduct themselves in the natural environment as a result of "knowledge, norms, [and] stereotypes," and recognizes the tension between the needs of society and the need for nature to preserve its systems and stability (Ridei, Rybalko, Kycherenko, Palamarchuk, \& Shofolov, 2013). It is "seen as the highest expression of human environmental education and environmental competence" (Ignatov, 2011, as cited in Elena, 2015).

Ecological culture is a complex concept as there are many systems, factors, and links needed to describe its feedback mechanisms. Aspects of feedback-guided analysis (Newell \& Proust, 2017a) will help show how feedback systems can help in the present study, which uses the cultural adaptation template introduced by Dyball and Newell (2015) as applied to the "culture-driven evolution of social-ecological systems." Concepts in each subsystem of this template find correspondence in equivalent systems of ASEAN countries.

\section{THE SUBSYSTEMS}

The four subsystems that affect each other in this model are the ASEAN Science and Environmental Policies, ASEAN Cultural Paradigms, State of the ASEAN Ecosystem, and the State of Human Health \& Well-Being (Figure 1). These are analogous to the States of Community, Cultural Paradigms, Ecosystem, and Human Health \& Well-Being in the original cultural adaptation template (Dyball \& Newell, 2015; Newell \& Proust, 2017b).

Figure 1 consists of four subsystems and seven links. The four subsystems are the

- ASEAN Cultural Paradigms-the shared worldviews of ASEAN countries (both as individuals and as a collective),

- ASEAN Science and Environmental Policies-the set of rules governing the promotion of science and environmental activities, 
- $\quad$ State of Human Health \& Well-Being - the general state of health and well-being of the ASEAN population, and

- $\quad$ State of the ASEAN Ecosystem-includes lands and seas as well as human activities and hazardous events.

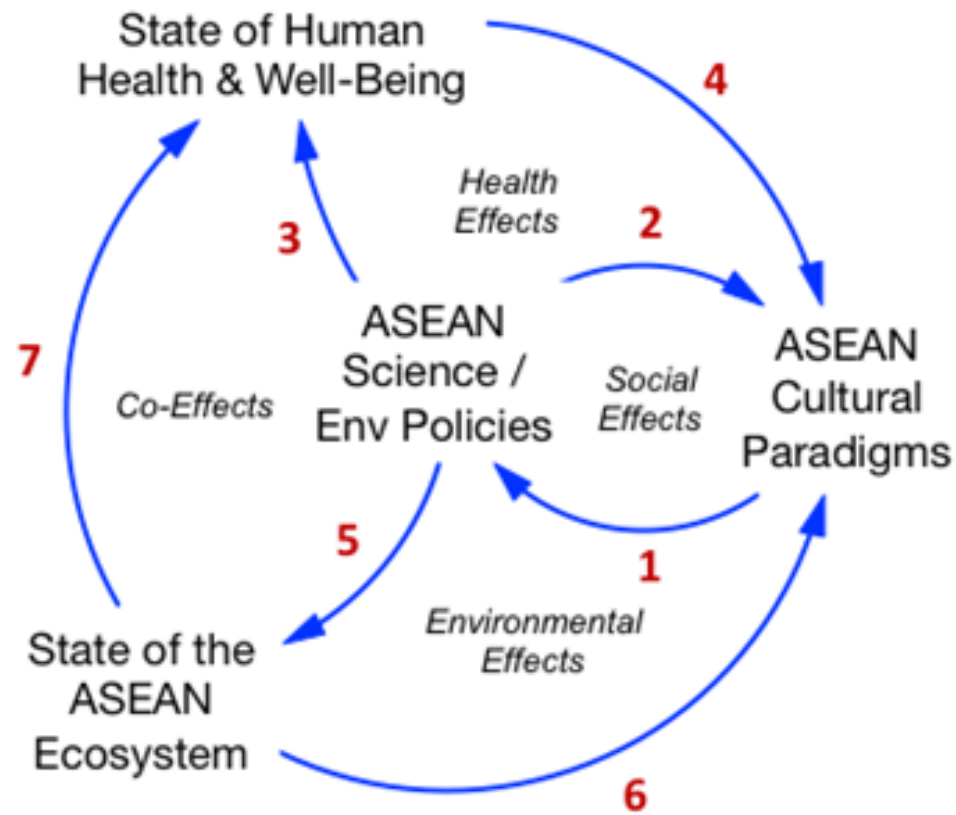

Figure 1: Variation of the Cultural Adaptation Template as Applied to the ASEAN Paradigm (adapted from Newell \& Proust [2017b] and Dyball \& Newell [2015])

The seven links are the influences of

1) ASEAN cultures and worldviews on ASEAN science and environmental policies,

2) ASEAN science and environmental policies on ASEAN cultures and worldviews,

3) ASEAN science and environmental policies on the state of health and well-being of ASEAN populations,

4) the state of health and well-being of ASEAN populations on ASEAN cultures and worldviews, 
5) ASEAN science and environmental policies on the state of the ASEAN ecosystem,

6) the state of the ASEAN ecosystem on ASEAN cultures and worldviews, and

7) the state of the ASEAN ecosystem on the state of health and wellbeing of ASEAN populations.

\section{ASEAN Science and Environmental Policies}

The ASEAN Science and Environmental Policies subsystem refers to the ASEAN's and its member countries' policies on science, the environment, and environmental education. These are the regulations that guide the formal institutions within ASEAN. Each country's policies, however, will have a stronger influence within its own borders as ASEAN is a loosely organized network that has no real support for the implementation (or sanctions for the non-implementation) of any individual member's policies.

While most of the policies of member countries are, in general, aligned with the ASEAN, there may be differences in implementation, such as with policies related to contested areas currently being occupied by China. This study, however, will focus on science policies that are heavily biased toward science, technology, and innovation (STI) given that the general direction of most ASEAN countries is to try and be more competitive economically (Bryne \& Parwell, 1996, as cited in Rigg, 2003). Such initiatives have been criticized for using a top-down approach, requiring more effective implementation, and lacking in support funding (Damuri et al., 2018; Narayanan \& Yew-Wah, 2018).

\section{ASEAN Cultural Paradigms}

The subsystem of ASEAN Cultural Paradigms, which can affect practices in resource use and waste management, refers to shared worldviews of ASEAN countries such as knowledge, mental models, beliefs, values, traditions, practices, and priorities, including those involving their relationship with nature. The GLOBE study (House, Hanges, Javidan, Dorfman, \& Gupta, 2004) found that Asian cultures are of two types, namely, the South Asian, which are characterized by strong family ties and deep concern for their communities, and the Confucian Asian, which are 
observed to be result-driven and tend to put more value on the group working together rather than on individual goals. Both cultures also reflect the importance of family obligations.

Some values observed in Asian families, such as wealth or materialism (Liao \& Wang, 2017) and commitment to family (House et al., 2004), may be practiced differently in rural and urban populations due to varying contexts. Migration across these areas is also prevalent (Kelly, 2011) due mostly to the perceived potential for greater prosperity in cities or lesser quality of life in rural provinces. While such migration highlights and meets short-term family needs or improved business productivity, it could affect environmental sustainability over the long-term. ASEAN countries (except for Singapore) tend to have a mixture of both urban and rural populations (see Table 1) which could shift in the next years as cities grow and require more land conversion, e.g., from agricultural land to industrial, commercial, and residential properties. This may also bring about a shift in the cultural paradigms that differentiate rural and urban populations.

\begin{tabular}{|c|c|c|c|}
\hline & & $\begin{array}{c}\text { \% Rural Population } \\
(2018)\end{array}$ & \% Urban Population (2018) \\
\hline 1 & Brunei Darussalam & 22.371 & 77.629 \\
\hline 2 & Cambodia & 76.612 & 23.388 \\
\hline 3 & Indonesia & 44.675 & 55.325 \\
\hline 4 & Lao PDR & 64.996 & 35.004 \\
\hline 5 & Malaysia & 23.964 & 76.036 \\
\hline 6 & Myanmar & 69.421 & 30.579 \\
\hline 7 & Philippines & 53.093 & 46.907 \\
\hline 8 & Singapore & 0 & 100 \\
\hline 9 & Thailand & 50.051 & 49.949 \\
\hline 10 & Viet Nam & 64.081 & 35.919 \\
\hline
\end{tabular}

Table 1: Percentage of Rural and Urban Populations in the ASEAN (World Bank, n.d.)

\section{The State of the ASEAN Ecosystem}

The State of the ASEAN Ecosystem is the subsystem that describes the environment, which includes both the ASEAN's rich biodiversity as well as its exposure to hazards brought about by climate change, extreme weather, geohazards from the Pacific Ring of Fire, and anthropological activities such as swidden 
agriculture, geopolitical tensions, and development from land reclamation, among others. Southeast Asian countries are also among the most frequently hit by tropical cyclones, tropical depressions, and earthquakes (Tan \& Fang, 2018; USGS, 2016).

The need to take resources from and dump waste into the natural environment for the sake of convenience and competitive advantage often clashes with the need to preserve it for future generations. Indeed, the actions of ASEAN countries in tapping their rich biodiversity for ecotourism and other economic activities have threatened various animal and plant species (Table 2) due to increases in market demand and other indirect factors like land conversion and climate change.

\begin{tabular}{|c|c|c|c|c|}
\hline & & \multicolumn{3}{|c|}{ Number of Threatened Species } \\
\hline & & Birds & Fishes & (Higher) Plant \\
\hline 1 & Brunei Darussalam & 31 & 14 & 127 \\
\hline 2 & Cambodia & 31 & 48 & 37 \\
\hline 3 & Indonesia & 160 & 166 & 458 \\
\hline 4 & Lao PDR & 29 & 55 & 56 \\
\hline 5 & Malaysia & 63 & 87 & 727 \\
\hline 6 & Myanmar & 56 & 53 & 61 \\
\hline 7 & Philippines & 93 & 91 & 254 \\
\hline 8 & Singapore & 22 & 29 & 62 \\
\hline 9 & Thailand & 62 & 106 & 159 \\
\hline 10 & Viet Nam & 52 & 83 & 231 \\
\hline
\end{tabular}

Table 2: Number of Threatened ASEAN Bird, Fish, and Higher Plant Species as of 2018 (World Bank, n.d.)

The effects of changing lifestyles due to urbanization in Asia are also very evident given high rates of mismanaged plastic waste (Table 3), with ASEAN countries contributing almost $28 \%$ of the worldwide total (almost the same as China's contribution).

\begin{tabular}{|c|c|c|c|}
\hline & & Million metric tons/year & $\begin{array}{c}\text { \%age of mismanaged } \\
\text { plastic waste }\end{array}$ \\
\hline 1 & China & 8.89 & 27.7 \\
\hline 2 & Indonesia* $^{*}$ & 3.22 & 10.1 \\
\hline 3 & Philippines $^{*}$ & 1.88 & 5.9 \\
\hline 4 & Vietnam* $^{*}$ & 1.83 & 5.8 \\
\hline
\end{tabular}




\begin{tabular}{|c|c|c|c|}
\hline & & Million metric tons/year & $\begin{array}{c}\text { \%age of mismanaged } \\
\text { plastic waste }\end{array}$ \\
\hline 5 & Sri Lanka & 1.59 & 5.0 \\
\hline 6 & Thailand* & 1.03 & 3.2 \\
\hline 7 & Egypt & 0.97 & 3.0 \\
\hline 8 & Malaysia* $^{*}$ & 0.94 & 2.9 \\
\hline 9 & Nigeria & 0.85 & 2.7 \\
\hline 10 & Bangladesh & 0.79 & 2.5 \\
\hline & *ASEAN component & 8.90 & 27.9 \\
\hline
\end{tabular}

Table 3: Top Ten Countries with Mismanaged Plastic Waste (Jambeck et al., 2015)

\section{The State of Human Health \& Well-Being}

While the description of the State of Human Health \& Well-Being subsystem includes the usual variables that are correlated with value fulfillment, such as physiological, psychological, happiness, and security factors, it also includes serious concerns.

Poverty remains to be a major challenge given that access to resources is necessary for achieving health and well-being. There is still a big poverty gap in many ASEAN countries; indeed, not all of them have found the right formula for inclusive development and prosperity. Most ASEAN countries still have populations that are living in poverty (except for Brunei and Singapore), undernourished (except for Singapore), and with underweight children below five years old (Table 4). These last two factors-undernourishment and the prevalence of underweight children below five years old-indicate a lack of proper physiological, psychological, and mental development that translates into a poor state of health and well-being, especially for the long-term.

The state of health and well-being is also threatened by conditions of the ecosystem such as air and water quality and the presence of vector-borne diseases (Table 5). 


\begin{tabular}{|c|c|c|c|c|c|c|c|}
\hline & & \multicolumn{2}{|c|}{$\begin{array}{c}\text { Poverty } \\
\text { headcount ratio at } \\
\text { national poverty } \\
\text { lines (\% of } \\
\text { population) }\end{array}$} & \multicolumn{2}{|c|}{$\begin{array}{c}\text { Prevalence of } \\
\text { undernourishment } \\
\text { (\% of population) }\end{array}$} & $\begin{array}{c}\text { Prevalence of } \\
\text { underweight, } \\
\text { weight for age } \\
\text { (\% of children } \\
\text { under } 5)\end{array}$ \\
\hline 1 & Brunei Darussalam & none & & 3.2 & 2017 & 9.6 & 2009 \\
\hline 2 & Cambodia & 17.7 & 2012 & 16.4 & 2017 & 23.9 & 2014 \\
\hline 3 & Indonesia & 9.8 & 2018 & 8.3 & 2017 & 19.9 & 2013 \\
\hline 4 & Lao PDR & 23.4 & 2012 & 16.5 & 2017 & 26.5 & 2011 \\
\hline 5 & Malaysia & 0.4 & 2015 & 2.5 & 2017 & 18.9 & 2016 \\
\hline 6 & Myanmar & 32.1 & 2015 & 10.6 & 2017 & 13.7 & 2016 \\
\hline 7 & Philippines & 21.6 & 2015 & 13.3 & 2017 & 21.5 & 2015 \\
\hline 8 & Singapore & none & & none & 2017 & 3.3 & 2000 \\
\hline 9 & Thailand & 8.6 & 2016 & 7.8 & 2017 & 6.7 & 2016 \\
\hline 10 & Viet Nam & 9.8 & 2016 & 9.3 & 2017 & 14.1 & 2015 \\
\hline
\end{tabular}

Table 4: ASEAN Poverty Headcount, Undernourishment, and Underweight Children Under 5 (as a percentage of the population [World Bank, n.d.])

\begin{tabular}{|c|c|c|c|c|}
\hline & & $\begin{array}{c}\text { Deaths caused by } \\
\text { non-communicable } \\
\text { diseases (\% of } \\
\text { total, 2016) }\end{array}$ & $\begin{array}{c}\text { Deaths caused } \\
\text { by communicable } \\
\text { diseases due } \\
\text { to maternal and } \\
\text { prenatal nutrition } \\
\text { conditions (\% of } \\
\text { total, 2016) }\end{array}$ & $\begin{array}{c}\text { Population } \\
\text { exposed to PM2.5 } \\
\text { air pollution levels } \\
\text { exceeding WHO } \\
\text { guideline value } \\
\text { (\% of total, 2017) }\end{array}$ \\
\hline 1 & Brunei Darussalam & 84.8 & 7.8 & 0 \\
\hline 2 & Cambodia & 64.4 & 25.6 & 100 \\
\hline 3 & Indonesia & 73.3 & 20.7 & 95.6 \\
\hline 4 & Lao PDR & 59.6 & 31.4 & 100 \\
\hline 5 & Malaysia & 73.6 & 17.5 & 90.5 \\
\hline 6 & Myanmar & 67.8 & 23.6 & 100 \\
\hline 7 & Philippines & 67.3 & 25.2 & 96.4 \\
\hline 8 & Singapore & 73.6 & 22.7 & 100 \\
\hline 9 & Thailand & 74.0 & 15.8 & 100 \\
\hline 10 & Viet Nam & 77.2 & 11.5 & 100 \\
\hline
\end{tabular}

Table 5: Death and Diseases (as a percentage of the population [World Bank, n.d.]) 


\section{THE LINKS}

Each of the seven links (indicated by arrows in Figure 1) signifies different processes and describes how one subsystem influences another. The first link (L1) describes how the cultures and worldviews of ASEAN countries influence the way their science and environmental policies are developed. As mentioned earlier, these mental models, beliefs, values, traditions, practices, and priorities influence policymaking as those who make policy are also familiar with these worldviews. ASEAN countries, for example, prioritize wealth linked to economic security and competitiveness. How, then, does this affect the choices of institutions or peoples when there are decisions to be made between long-term environmental sustainability and short-term needs that highlight concerns for family or improved business results? Greater awareness, therefore, from the ecological education of populations will eventually make it possible for people to develop lifestyles that promote social and environmental good and internalize such into their value systems.

The second link (L2), on the other hand, shows how insights from science and environmental policies and their implementation affect worldviews. As mentioned in the opening statement, policies reinforce the need to be innovative, which could encourage people to go into activities that support innovation and push them to achieve prosperity.

The third link (L3) is about how the implementation of science and environmental policies and related human actions can lead to improved human health and well-being. Most ASEAN countries have policies that push for economic security and competitiveness that have led to improved GDP as well as value fulfillment for the middle and upper classes in terms of wealth and security. Yet these same policies can contribute to the gap between the haves and the have-nots in countries where there is inequitable distribution. Policies that favor economic growth, for example, tend to allow companies to keep wages low, maintain poor working environments, and violate human rights (Rigg, 2003).

The fourth link (L4) looks into how the state of human health and well-being in the ASEAN affects worldviews and cultures. A good state of health and well-being, on the one hand, affords people a chance to think about how to contribute to an ecological culture without worrying about fighting for survival against poverty, disease, or both. On the other hand, those in a poor state of health and well-being 
tend to reinforce the prioritization of wealth and health in their value system, albeit more as a reaction to their situation. This can be a reinforcing loop that will have negative effects on the environment, particularly in the absence of factors like ecological education which can show how the environment also factors into human health and well-being. Increasing urbanization in Southeast Asia and the perception that life is better in the city, for instance, have led to the phenomenon of migration, including rural to urban migration (Kelly, 2011).

The fifth link (L5) is about how the implementation of science and environmental policies and related human actions can affect the ASEAN ecosystem. Here there is some tension between the implementation of STI policies that favor economic growth vis-á-vis environmental policies that preserve states of biodiversity, improve air and water quality, and help in climate change mitigation. Bryne and Parwell (1996, as cited in Rigg, 2003) observed that in this region, "perhaps more than anywhere else in the developing world, the contradictions between environment and development, economic growth and environmental conservation, are visible." A case in point was made by Hart-Landsberg and Burkett (1998, as cited in Rigg, 2003), who observed that "the 'central contradiction' in export-led growth is revealed in Thailand's environmental destruction." According to Rigg (2003), the effects of policies that push for innovation, economic competitiveness, and consumer-led economic growth also tend to lead to a "culture of consumerism, individualism, greed, and acquisitiveness replacing local traits that stress community action, consensus, [and] moderation." The transboundary nature of environmental concerns, moreover, should also be considered in the development of ASEAN environmental policies. The "ASEAN Way," which refers to member states respecting each other's sovereignty through the principle of non-interference, is not without criticism as it has resulted in a lack of sanctions for non-compliance (Aggarwal \& Chow, 2010, as cited in Pramudianto, 2018); indeed, Koh and Robinson (2002, as cited in Pramudianto, 2018) stated that this is observed "at the cost of the environment." Nevertheless, there have been some agreements translated into country policies that highlight the importance of sustainable development (Pramudianto, 2018).

The sixth link (L6), which is about how the state of the ASEAN ecosystem affects worldviews and cultures, probably requires more time for experiential learning. A level of awareness that can actually move populations to shift their practices and priorities is needed, particularly with the help of mediators like a well-thought-out 
ecological education program and information and communication strategies that explicitly articulate the connection between culture, lifestyle, and the state of the ecosystem. ASEAN populations have at different points in time experienced extreme weather events, the mismanagement of plastic waste in Asian rivers that ended up in the seas of the region (Schmidt, Krauth, \& Wagner, 2017), the loss of biodiversity that affected fishing and farming (IUCN, 2018), and deteriorating air quality due to haze and vehicle emissions, among others. Through proper learning and reflection, these experiences can influence culture and mindsets in favor of the environment.

The final link (L7) looks into how changes in the ASEAN ecosystem affect human health and well-being. The beauty of the ASEAN environment in and of itself can promote human health and well-being, and yet appreciation for it is often at the mercy of players who want to exploit its resources without any long-term view in mind. In the case of Indonesia, for example, Damuri, Aswicahyono, and Christian (2018) wrote that the country's "economic growth has been driven primarily by natural resources and trade rather than by science and innovation."

A proper study of these links and subsystems can thus show that feedback mechanisms may actually lead to undesirable consequences. Science policies that promote STI, for example, particularly the commercialization of new technologies such as for locally-manufactured automobiles, would reinforce national pride (L2) which could, in turn, push the development and implementation of said policies even further (L1). The two links would thus constitute a reinforcing loop.

Policies also influence the state of human health and well-being as well as the state of the ecosystem, e.g., a policy could provide livelihood and improve the quality of people's lives (L3) but while also encouraging production processes that not only depend heavily on resources like metal, fossil fuel, water, and other materials from the environment but also produce carbon emissions and other pollutants (L5). This would lead to negative effects on the ecosystem, such as poor air quality and the urban heat island effect, which would, in turn, compromise the well-being of the population (L7). L5 and L7, at least in this case, would thus have opposite effects on health and well-being.

The way people perceive the state of their health and well-being may depend as well on their own experience and exposure to the situation. Some, for example, may tend to overlook the negative health effects produced by their livelihoods if the 
latter meet their basic economic needs. Those who get sick, on the other hand, such as from exposure to pollution, may eventually value health more. Either way, they reinforce the cultural paradigms of health and wealth, albeit according to different priorities (L4). People may learn, therefore, to include the ecosystem in their cultural paradigm if they can connect it with the situations they experience (L6). This, in turn, could put pressure on the implementation of environmental policies even as those for STI are continued (L1).

\section{APPLICATIONS OF THE CULTURAL ADAPTATION TEMPLATE}

One application of this template is in the promotion of innovation in automotive-related industries. The traditional Asian value of wealth, which can be translated into prosperity, has driven science policies to focus on means for attaining prosperity (L1), such as the push for innovation that can be commercialized. Indonesia, Malaysia, the Philippines, Thailand, and Viet Nam have all invested in research and development as well as in commercial initiatives to varying degrees, ranging from tax incentives in Indonesia to government-linked businesses in Malaysia, public funding for innovation in Thailand, and skills development in the Philippines and Viet Nam (Anbumozhi \& Intal, 2015; ADB \& Ministry of Finance Republic of Indonesia, 2020; Wad \& Govindaraju, 2011; UNCTAD, 2015; Truong \& Nguyen, 2011). Such incentives in turn reinforce the traditional values of wealth and prosperity (L2).

The growth of the automotive industry, particularly in Malaysia, Thailand, and Indonesia, has led to employment and economic growth (L3), which in turn have reinforced the aforementioned traditional values (L4). This industry, however, changes the state of the ecosystem by its very nature, e.g., through the extraction of natural resources (metal, petroleum, rubber); emissions from the processing of these resources and increased vehicular traffic; and increases in water usage and carbon footprints (L5). Such changes in the state of the ecosystem could influence cultures and worldviews, albeit over a longer time frame, when people eventually see the destruction of natural resources that are part of the pride and heritage of their countries (L6). There are short-term effects as well, such as on peoples' health and well-being as indicated by the less than satisfactory air quality in most ASEAN cities and the rise of respiratory diseases (L7). The population's awareness of these 
health repercussions can therefore increase the value it places on health as part of society's cultural paradigm (L4).

We thus observe two competing effects coming from the impacts of ASEAN policies and the state of the ASEAN ecosystem on the state of human health and wellbeing. Other competing effects come from the various influences ASEAN policies, the state of health and well-being, and the state of the ASEAN ecosystem have on the ASEAN cultural paradigm.

Depending on which impacts affect the population the most, the state of the cultural paradigm can affect science and environmental policies once again (L1). This is confirmed by various laws and administrative regulations that address traffic, pollution, and disaster resiliency. Such an altered state of events may also get the government to push for policies that support environment-friendly technology. In the case of Thailand and Indonesia, for example, the government exempted low-cost, fuel-efficient cars from luxury taxes, leading to the development of Thailand's Eco Car program and Indonesia's Low Cost Green Car (LCGC) policy (Maikaew, 2018; Suzuki, 2016).

These combined changes in the state of the ecosystem (increased traffic and air pollution) along with science policies that push for commercial innovation could lead to a particular state of health and well-being (i.e., discomfort from traffic and pollution along with having increased income) as seen in the L7 and L3 links. This could, in turn, prioritize the value of convenience (L4), a new aspect of modern culture that could lead to policy support for creative solutions (L1) such as the approval and regulation, especially in congested cities, of food delivery apps based on sharing economy platforms (e.g., GrabFood, Food Panda). These apps, however, inevitably use more food packaging (vs. dine-in orders) made of single-use plastics (Li, Mirosa, \& Bremer, 2020). The policies that allow these delivery systems to operate thus end up influencing the ecosystem as well (L5).

Another application at the heart of which is the state of human health and wellbeing is in the new states and events caused by the COVID-19 pandemic. The idea of order and control is deemed to be important in most ASEAN societies, and probably to a greater degree compared to non-Asians as it stems from an Asian collectivist mindset (Sastry \& Ross, 1998; House et al., 2004). It was thus acceptable for Asian governments to impose lockdowns without big social events and widespread protests 
like those experienced in Europe and the United States (Cheung, 2020; Hutton, 2020) (L1). In cases like the Philippines, which eased restrictions earlier than most other ASEAN countries and without sufficient precautionary measures, government policies stemmed a confluence of economic concerns, power beliefs, and perceptions that bureaucracy works in silos (L1). Nevertheless, the policies on lockdowns and strict implementation of regulations developed a sense of caution among many in the population (L2) and were deemed to be important for keeping the state of health and well-being under reasonable control (L3). Yet while more people learned to value health as they experienced the negative impacts of the pandemic, they placed it on the same level as economic gains when their livelihoods were put at risk (Bonquin, 2020) (L4).

Lockdown policies have also reinforced the need for delivery apps and online shopping venues (McKinsey \& Company, 2020), effectively increasing the amount of single-use packaging circulating in the ecosystem (L5). With the amount of waste that needs to be managed, it would be interesting to see the long-term effects this would have on the state of human health and well-being (L7), especially given that Southeast Asia already has problems with its mismanaged plastic waste to begin with. Indeed, while this new state of the ecosystem has made more people aware of the packaging waste they accumulate from deliveries, they still expect governments to do more regarding the problem (UNEP \& FIA, 2020) (L6).

\section{THE ROLE OF ECOLOGICAL EDUCATION}

This paradigm shows that science and environmental policies, no matter how well-intentioned and well-implemented they may be, can have unintended consequences due to feedback mechanisms that flow through different subsystems. If the end goal of policy is the well-being and prosperity of a country and its population, it is important to look at initiatives that consider cultural paradigms alongside the ecosystem.

One of the sources of great concern particularly in the ASEAN region is the destruction of environmental systems as manifested in global warming, extreme weather patterns and events, climate change, the depletion of marine and forest resources, diminishing access to clean water resources, and decreased air quality, among many others. Potential solutions to these problems require an understanding 
of both systems and the feedback that happens among different subsystems. It is important to frame this understanding using the nested domain concept of sustainability, i.e., that economy and society operate within the context of the natural environment, depending on it for resources while also having an impact on it (Giddings, Hopwood, \& O’Brien, 2002; Future-Fit Foundation, 2016; Fairfield, 2018).

The applications in the previous section highlight the role of ecological education and culture in ensuring that policymakers, executive officers, influencers, and consumers make informed and sustainable choices. While it may seem more natural to think that immediate, short-term needs are primary, a good ecological education, which has to begin at a young age, might help a generation be more willing to lead lifestyles that consider the common social and environmental good, including the long-term sustainability of the environment. Part of this ecological education is the development of a critical perspective that mediates one's experience of the declining states of the ecosystem (L6) and of human health and well-being (L4) toward a more sustainable worldview. Such a paradigm shift could affect how science and environmental policies are made (L1), with well-thought-out policies reinforcing sustainable worldviews (L2) in turn. Indeed, when policies are developed with the proper ecological and systems mindset, there will be a greater chance that the interplay of factors and possible scenarios will be taken into consideration in ways that will make their impact on the states of human health and well-being (L3) and of the ecosystem (L5) turn out to be positive. This can lead to an improved state of human health and well-being (L7) as well given that ecological education improves the state of the ecosystem despite natural hazards that can harm it.

While individuals have to play their part in ensuring that stakeholders develop mindsets and habits that consider the ecosystem, institutions also have a responsibility to promote ecological education. Educational institutions, for instance, need to keep students, faculty, and other stakeholders attuned to the changing context of our world, a world that has sometimes been described as volatile, uncertain, complex, and ambiguous (VUCA; see Johansen, 2012; Lawrence, 2013). Efforts need to be made to help them see the connections between material needs and consumer goods, energy and materials taken from the environment, and waste materials returned thereto. Such a sustainability mindset, moreover, needs to be translated even further into peoples' decision-making, lifestyles, and cultures. It is not about a "series of urgent and partial responses to the immediate problems 
of pollution, environmental decay and the depletion of natural resources"; rather, "there needs to be a distinctive way of looking at things, a way of thinking, policies, an educational programme, a lifestyle and a spirituality" (Francis, 2015: no. 111).

Businesses and organizations also need to manage their own cultures to reduce resource consumption and waste production. Many organizational and operational models have been proposed to guide such efforts, e.g., creation of sustainable value (Hart \& Milstein, 2003), creation of shared value (Porter \& Kramer, 2011), becoming a sustainability winner (Lubin \& Esty, 2010), and joining the circular economy (Murphy \& Rosenfield, 2016). While these models are not perfect frameworks, they contain suggestions on how to create sustainable corporate strategies.

\section{CONCLUSION}

The use of the cultural adaptation template (Newell \& Proust, 2017b; Dyball \& Newell, 2015) in feedback-guided analysis is a novel approach to analyzing issues and developing strategic interventions. As a method of systems thinking, it makes possible a better understanding of the feedback mechanisms that could ultimately improve population health and well-being. As such, while it will not necessarily solve problems immediately due to several factors like inefficient implementation systems, this approach can help policymakers find better ways to coordinate initiatives and, more importantly, consult with stakeholders for better insights into the influence one subsystem has with another.

Ecological education can mediate the development of a more sustainable worldview, i.e., a worldview and mindset that considers environmental, social, and economic factors all at the same time. This is a "leverage point," a strategic intervention that can "produce large changes" (Proust et al., 2012: 2136); indeed, such a shift toward ecological culture can affect the three other subsystems through various links. Moreover, while such an intervention preferably begins at an early age so that a generation will have the same or similar worldviews, it can nevertheless be prepared for all generations or for anyone who has experienced the negative impacts of climate change, mismanaged waste, the depletion of resources, corruption, violations of human rights, a lack of respect for Creation-the list goes on. 
This template for feedback-guided analysis is a good mental model not just for any policymaker or business organization but also for any individual who consumes resources and produces waste. It ultimately highlights the need for an ecological culture and lifestyle that challenges both individuals and institutions. This kind of mental model can help in the development of effective science and environmental policies as it visualizes that "complex ecosystem of effective institutions, laws, rules, and regulations that are managed by able and effective public officials and strongly supported by the private sector" (Lim, 2018: 213).

This kind of mental model for feedback-guided analysis thus represents possibilities for the development of an ecological culture, one that promotes a sustainable lifestyle informed by long-term possibilities and complex consequences. Indeed, it is a template for promoting a culture that cares for others and our common home.

\section{REFERENCES}

ADB [Asian Development Bank] \& Ministry of Finance Republic of Indonesia. 2020. Innovate Indonesia: Unlocking growth through technological transformation. Mandaluyong City, Philippines: Asian Development Bank. Available at https:// www.adb.org/sites/default/files/publication/575806/innovate-indonesiaunlocking-growth.pdf (accessed October 27, 2020).

Ambashi, M. 2018. Introduction to innovation policy in ASEAN. In M. Ambashi (Ed.), Innovation policy in ASEAN: 1-22. Jakarta: Economic Research Institute for ASEAN and East Asia. Available at http://www.eria.org/uploads/media/ Innovation_Policy_in_ASEAN.pdf.

Anbumozhi, V., \& Intal, P., Jr. 2015. Can thinking green and sustainability be an economic opportunity for ASEAN? ERIA Discussion Paper Series No. 66. Jakarta: Economic Research Institute for ASEAN and East Asia. Available at https://www. eria.org/ERIA-DP-2015-66.pdf.

Anbumozhi, V., \& Kojima, M. 2019. Resilience and environmental sustainability. In F. Kimura, V. Anbumozhi, \& H. Nishimura (Eds.), Transforming and deepening the 
ASEAN community: 72-104. Jakarta: Economic Research Institute for ASEAN and East Asia. Available at https://www.eria.org/uploads/media/0.AV2040_VOL3.pdf.

Bonquin, C. 2020. Health or wealth amid the COVID-19 crisis? Finance exec says "both." CNN Philippines, July 10. Available at https://www.cnnphilippines.com/ news/2020/7/10/COVID-19-Philippines-economy-health.html.

Chandran, R., Gunawardena, C., \& Castro, N. 2017. The national environmental education action plan 2018-2040. Quezon City: Department of Environment and Natural Resources.

Cheung, H. 2020. Coronavirus: What could the West learn from Asia? BBC News, March 21. Available at https://www.bbc.com/news/world-asia-51970379.

Damuri, Y. R., Aswicahyono, H., \& Christian, D. 2018. Innovation policy in Indonesia. In M. Ambashi (Ed.), Innovation policy in ASEAN: 96-127. Jakarta: Economic Research Institute for ASEAN and East Asia. Available at http://www. eria.org/uploads/media/Innovation_Policy_in_ASEAN.pdf.

Dyball, R., \& Newell, B. 2015. Understanding human ecology: A systems approach to sustainability. London: Routledge.

Elena, V. A. 2015. The development of ecological culture of students in the design and creative activity. Procedia-Social and Behavioral Sciences, 191: 2329-2333.

Fairfield, K. 2018. Educating for a sustainability mindset. Journal of Management for Global Sustainability, 6(1): 21-44.

Francis. 2015. Laudato si': On care for our common home. Vatican City: Libreria Editrice Vaticana. Available at http://w2.vatican.va/content/dam/francesco/pdf/ encyclicals/documents/papa-francesco_20150524_enciclica-laudato-si_en.pdf.

Future-Fit Foundation. 2016. Future-Fit business benchmark part 1: Concepts, principles and goals. Available at https://seproject.org/wp-content/ uploads/2019/11/SSI-Future-Fit-Business-Benchmark-Part-1.pdf. 
Giddings, B., Hopwood, B., \& O’Brien, G. 2002. Environment, economy and society: Fitting them together into sustainable development. Sustainable Development, 10(4): 187-196.

Hart, S. L., \& Milstein, M. B. 2003. Creating sustainable value. Academy of Management Perspectives, 17(2): 56-67.

House, R. J., Hanges, P. J., Javidan, M., Dorfman, P. W., \& Gupta, V. 2004. Culture, leadership, and organizations: The GLOBE study of 62 societies. Thousand Oaks, CA: Sage Publications.

Hutton, W. 2020. Western societies have failed the deadly Covid test. They must learn lessons from Asia. The Guardian, November 1. Available at https://www. theguardian.com/commentisfree/2020/nov/01/western-societies-have-failedthe-deadly-covid-test-they-must-learn-lessons-from-asia.

IUCN [International Union for Conservation of Nature]. 2018. IUCN 2017. Asia Regional Office Annual Report 2017. Bangkok: IUCN Asia. Available at https:// portals.iucn.org/library/sites/library/files/documents/2018-041-En.pdf.

Jambeck, J. R., Andrady, A., Geyer, R., Narayan, R., Perryman, M., Siegler, T. R., Wilcox, C., \& Law, K. L. 2015. Plastic waste inputs from land into the ocean. Science, 347(6223): 768-771.

Johansen, B. 2012. Leaders make the future (2nd ed.). San Francisco, CA: BerrettKoehler Publishers, Inc.

Kelly, P. F. 2011. Migration, agrarian transition, and rural change in Southeast Asia. Critical Asian Studies, 43(4): 479-506.

KOICA [Korea International Cooperation Agency] \& KISTEP [Korea Institute of S\&T Evaluation and Planning]. 2013. Cambodia's national science and technology master plan (2014-2020). Cambodia: Royal Government of Cambodia.

Lawrence, K. 2013. Developing leaders in a VUCA environment. Chapel Hill, NC: UNC Executive Development. 
Li, C., Mirosa, M., \& Bremer, P. 2020. Review of online food delivery platforms and their impacts on sustainability. Sustainability, 12(14): 5528.

Liao, J., \& Wang, L. 2017. The structure of the Chinese material value scale: An Eastern cultural view. Frontiers in Psychology, 8: Article 1852.

Lim, H. 2018. Innovation policy in Singapore. In M. Ambashi (Ed.), Innovation policy in ASEAN: 198-217. Jakarta: Economic Research Institute for ASEAN and East Asia. Available at http://www.eria.org/uploads/media/Innovation_Policy_ in_ASEAN.pdf.

Lubin, D. A., \& Esty, D. C. 2010. The sustainability imperative. Harvard Business Review, 88(5): 42-50.

Maikaew, P. 2018. Mass-market eco-car stimulus on the way. Bangkok Post, Nov. 8. Available at https://www.bangkokpost.com/business/1571950/mass-market-ecocar-stimulus-on-the-way (accessed October 27, 2020).

McKinsey \& Company. 2020. Perspectives on retail and consumer goods, No. 8 (August). Available at https://www.mckinsey.com/ /media/McKinsey/Industries/ Retail/Our\%20Insights/Perspectives\%20on\%20retail\%20and\%20consumer\%20 goods\%20Number\%208/Perspectives-on-Retail-and-Consumer-Goods_Issue-8.pdf.

Mokthsim, N., \& Salleh, K. O. 2014. Malaysia's efforts toward achieving a sustainable development: Issues, challenges and prospects. Procedia-Social and Behavioral Sciences, 120: 299-307.

Murphy, C., \& Rosenfield, J. (Eds.). 2016. The circular economy: Moving from theory to practice. McKinsey Center for Business and Environment Special Edition. McKinsey \& Company.

Narayanan, S., \& Yew-Wah, L. 2018. Innovation policy in Malaysia. In M. Ambashi (Ed.), Innovation policy in ASEAN: 128-162. Jakarta: Economic Research Institute for ASEAN and East Asia. Available at http://www.eria.org/uploads/ media/Innovation_Policy_in_ASEAN.pdf. 
Newell, B., \& Proust, K. 2017a. Escaping the complexity dilemma. In A. König \& J. Ravetz (Eds.), Sustainability science: 96-112. London \& NY: Routledge.

Newell, B., \& Proust, K. 2017b. The bigger picture-seeing the complexity. Conference presentation at the Advanced Institute on Disaster Risk Reduction with Systems Approach for Slow-Onset Climate Disasters, Taipei.

Porter, M. E., \& Kramer, M. R. 2011. Creating shared value. Harvard Business Review, January-February: 1-17.

Pramudianto, A. 2018. ASEAN commitment to sustainable development in the regional international environmental law perspective. International Relations and Diplomacy, 6(3): 171-187.

Proust, K., Newell, B., Brown, H., Capon, A., Browne, C., Burton, A., Dixon, J., Mu, L., \& Zarafu, M. 2012. Human health and climate change: Leverage points for adaptation in urban environments. International Journal of Environmental Research and Public Health, 9: 2134-2158.

Quimba, F. M. A., Albert, J. R. G., \& Llanto, G. M. 2018. Innovation policy in the Philippines. In M. Ambashi (Ed.), Innovation policy in ASEAN: 163-197. Jakarta: Economic Research Institute for ASEAN and East Asia. Available at http://www. eria.org/uploads/media/Innovation_Policy_in_ASEAN.pdf.

Rattanakhamfu, S., \& Tangkitvanich, S. 2018. Innovation policy in Thailand. In M. Ambashi (Ed.), Innovation policy in ASEAN: 218-246. Jakarta: Economic Research Institute for ASEAN and East Asia. Available at http://www.eria.org/ uploads/media/Innovation_Policy_in_ASEAN.pdf.

Ridei, N., Rybalko, Y., Kycherenko, Y., Palamarchuk, S., \& Shofolov, D. 2013. The role of ecological culture as an indicator of sustainable development of relations between society and nature. European Scientific Journal, 9(10): 14-23.

Rigg, J. 2003. Southeast Asia: The human landscape of modernization and development (2nd ed.). London \& NY: Routledge.

Sastry, J., \& Ross, C. E. 1998. Asian ethnicity and the sense of personal control. Social Psychology Quarterly, 61(2): 101-120. 
Schmidt, C., Krauth, T., \& Wagner, S. 2017. Export of plastic debris by rivers into the sea. Environmental Science \& Technology, 51(21): 12246-12253.

Smith, G. A., \& Williams, D. R. 1999. Ecological education: Extending the definition of environmental education. Australian Journal of Environmental Education, 15: 139-146.

Socialist Republic of Viet Nam. 2012. Viet Nam sustainable development strategy for 2011-2020. Socialist Republic of Viet Nam Government Portal. Available at http://www.chinhphu.vn/portal/page/portal/English/strategies/strategiesdetail s?categoryId=30\&articleId=10050825.

Suzuki, J. 2016. Low-cost green cars leading sales rally in Indonesia. Nikkei Asia, November 11. Available at https://asia.nikkei.com/Business/Low-cost-green-carsleading-sales-rally-in-Indonesia (accessed August 21, 2019).

Tan, C., \& Fang, W. 2018. Mapping the wind hazard of global tropical cyclones with parametric wind field models by considering the effects of local factors. International Journal of Disaster Risk Science, 9(1): 86-99.

Tay, S. S. C., \& Tijaja, J. P. (Eds.). 2017. Global megatrends: Implications for the ASEAN economic community. Jakarta: ASEAN Secretariat \& Singapore Institute of International Affairs.

Truong, T. C. B., \& Nguyen, M. L. 2011. Development of automotive industries in Vietnam with improving the network capability. In P. Intarakumnerd (Ed.), How to enhance innovation capability with internal and external sources, ERIA Research Project Report 2010-9: 273-307. Jakarta: Economic Research Institute for ASEAN and East Asia. Available at https://www.eria.org/uploads/media/ResearchProject-Report/RPR_FY2010_9_Chapter_6.pdf (accessed October 27, 2020).

UNCTAD [United Nations Conference on Trade and Development]. 2015. Science, technology \& innovation policy review-Thailand. New York \& Geneva: United Nations. Available at https://unctad.org/system/files/official-document/ dtlstict2015d1_en.pdf (accessed October 2, 2020).

UNEP [United Nations Environment Programme] \& FIA [Food Industry Asia]. 2020. Consumers and business concerned about plastic waste but expect governments 
to do more. June 23. Available at https://www.unenvironment.org/news-andstories/press-release/report-consumers-and-business-concerned-about-plasticwaste-expect (accessed November 20, 2020).

USGS [United States Geological Survey]. 2016. The severity of an earthquake. Available at https://pubs.usgs.gov/gip/earthq4/severitygip.html.

Vo, T. T., Nguyen, A. D., \& Dinh, T. H. 2018. Innovation policy in Viet Nam. In M. Ambashi (Ed.), Innovation policy in ASEAN: 247-276. Jakarta: Economic Research Institute for ASEAN and East Asia. Available at http://www.eria.org/ uploads/media/Innovation_Policy_in_ASEAN.pdf.

Wad, P., \& Govindaraju, V. G. R. C. 2011. Automotive industry in Malaysia: An assessment of its development. International Journal of Automotive Technology and Management, 11(2): 152-171.

World Bank. n.d. Databank | World development indicators. Available at https:// databank.worldbank.org/source/world-development-indicators.

Maria Assunta C. Cuyegkeng is the director of the Ateneo Institute of Sustainability. She is a Professor at the Department of Leadership \& Strategy of the John Gokongwei School of Management, Ateneo de Manila University and holds a PhD in Chemistry from the University of Regensburg, Germany. Her current research interests are in the fields of sustainability management, change leadership, and quality assurance.

Charlotte Kendra Gotangco Gonzales is the program manager for Climate Change and Disaster Risk of the Ateneo Institute of Sustainability and an Associate Professor of the Department of Environmental Science of the Ateneo de Manila University. She holds a $\mathrm{PhD}$ in Earth and Atmospheric Sciences from Purdue University, U.S.A. and is currently working on applying systems thinking approaches to issues related to sustainability and resilience. 